\title{
Fifteen years of design, construction and monitoring of soil covers on Wismut's uranium mining legacy sites - a synopsis
}

\author{
U. Barnekow Department Mine Remediation/Geotechnics, Wismut GmbH, Germany \\ M. Paul Division Engineering/Radiation Protection, Wismut GmbH, Germany
}

\begin{abstract}
In East Germany, uranium mining and milling by the Soviet-German Wismut company took place from 1946 to 1990 and involved production of 216,000 $t$ of uranium. In 1990, the legacy sites enclosed five underground mines, contaminated operational areas $\left(37 \mathrm{~km}^{2}\right), 60+$ waste rock dumps $\left(325\right.$ million $\left.\mathrm{m}^{3}\right)$, an open pit $\left(1.6 \mathrm{~km}^{2}\right)$ and six large mill tailings ponds $\left(5.7 \mathrm{~km}^{2}, 160\right.$ million $\left.\mathrm{m}^{3}\right)$. In 1991 the German federal government committed $€ 6.6$ billion to the remediation of the sites and founded Wismut GmbH to take responsibility for decommissioning and remediation. In 2012, Wismut met its responsibilities to carry out works with a budget of $€ 144$ million.

The materials to be covered are usually classified as radioactive matter and are susceptible to acid rock drainage. The underground mine workings, waste rock dumps and tailings ponds are sources of radiation exposure and contaminated seepage. According to German mining law, decommissioning of uranium mining and milling sites is required to eliminate acute risks and reduce the environmental impact. With regard to radiation protection of the local public, the effective dose must be reduced to below $1 \mathrm{mSv} /$ year after decommissioning.

This paper presents a synopsis of at least 15 years of design, construction and monitoring experience with soil covers on Wismut's uranium mining legacy sites. Soil cover types have been designed to address the following remediation objectives: prevent direct access to radioactive matter by the public, prevent external radiation (direct radiation and dusting), limit radon exhalation, limit oxygen intrusion, provide a stable plant-available water supply for vegetation, control or minimise net percolation through the cover and vegetate. Since the 1990s, Wismut has placed soil covers on numerous waste rock dumps, mill tailings ponds and the backfilled Lichtenberg open pit as well as contaminated sites. Soil-hydrological monitoring stations have been installed to measure the day-to-day water balance. These stations were usually equipped with lysimeters and sensors to continuously measure unsaturated water flow, soil suction and water content in the cover system.
\end{abstract}

The climate at Wismut varies due to topography and can be characterised as moderately humid with average temperatures of $c a .8 .5^{\circ} \mathrm{C}$ and a central European winter and summer season. Cover types include (a) two-layer covers designed particularly with respect to radon exhalation; (b) single-layer and two-layer covers designed according to store-and-release principles as well as with respect to radon exhalation and oxygen intrusion; and (c) multilayer-type covers currently planned for the future to be built on partial areas of Culmitzsch tailings pond. The paper concludes with the outlook for long-term stewardship.

\section{Introduction}

In East Germany, uranium mining and milling by the Soviet-German Wismut company took place from 1946 to 1990 with the production of $216,000 \mathrm{t}$ of uranium. In 1990, the legacy sites included five underground mines, contaminated operational areas $\left(37 \mathrm{~km}^{2}\right), 60+$ waste rock dumps (WRDs) $\left(325\right.$ million $\left.\mathrm{m}^{3}\right)$, an open pit $\left(1.6 \mathrm{~km}^{2}\right)$ and six large mill tailings ponds $\left(5.7 \mathrm{~km}^{2}, 160\right.$ million $\left.\mathrm{m}^{3}\right)$. In 1991 the German federal government committed $€ 6.6$ billion and founded Wismut $\mathrm{GmbH}$ to be responsible for decommissioning and remediation. In 2012, Wismut covered works with an annual budget of $€ 144$ million. The waste rock to be covered is classified as radioactive matter and susceptible to acid rock drainage (ARD). The underground 
mine workings, waste rock dumps and tailings ponds are sources for radiation exposure and contaminant seepage. According to German mining law, decommissioning of uranium mining and milling sites is required to eliminate acute risks and reduce environmental impact. With regard to radiation protection of the local public, the effective dose shall be reduced to below $1 \mathrm{mSv} /$ year after decommissioning.

Early in the uranium mining period, numerous mining sites located in the ore mountains region were operated and abandoned. Until the 1960s, mining sites including their waste rock dumps were often demolished and abandoned with a minimum of securing measures and usually without any placement of soil covers.

The first rehabilitation works on waste rock dumps started during the 1960s. Waste rock dumps were reshaped and covered with recultivation soil. Such soil could be waste rock material, such as the mixedgrained soil from decomposed overburden rock used at Seelingstaedt or the loam used in the Ronneburg mining area. In the ore mountains region, many waste rock dumps were reshaped and recultivation soil was placed as a thin layer $(5-15 \mathrm{~cm})$ and/or filled into holes excavated to plant trees for afforestation. The major purpose of these measures was to reduce acute risks associated with geotechnical and erosional stability and to revegetate the respective areas.

During the same period, a number of closed uranium mill tailings ponds were also partly covered with various types of fill (waste rock material, construction debris, soil materials). As an example, an interim cover consisting of mixed-grained soil was placed on air-exposed sandy mill tailings surfaces to avoid radioactive dusting on Trünzig tailings pond near the Seelingstaedt mill (Thuringia) as well as on Helmsdorf tailings pond nearby Crossen mill (Saxony).

After the reunification of Germany during the 1990s, monitoring systems were installed to assess the existing situation with respect to radiation exposure to the public, geotechnical risks and environmental impact. Numerous abandoned mining sites were rapidly investigated and the first securing measures were taken against acute risks. On a limited number of selected sites, additional remedial works were carried out. For instance, on the tailings pond J1 of the site Dammhalde/Trockenbecken (Johanngeorgenstadt) fill materials were used for reshaping and approximately $1 \mathrm{~m}$ of thick soil cover was placed on the entire tailings surface and then grass seeded.

This paper presents a synopsis of at least 15 years of design, construction and monitoring of soil covers on Wismut's uranium mining legacy sites. Figure 1 shows a map of the locations of the different former uranium mining and milling sites and indicates the respective sites discussed in more detail in this paper. 


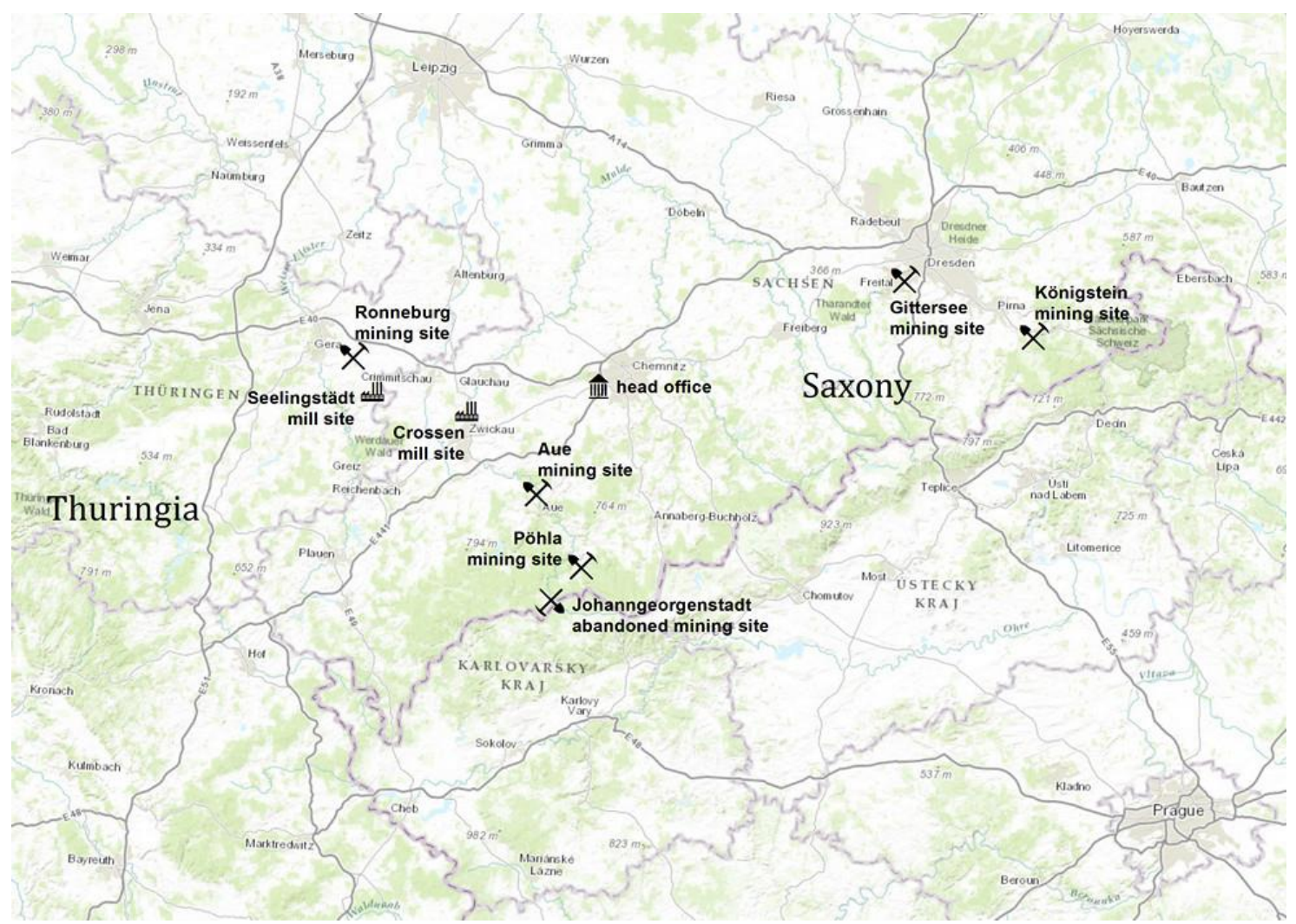

Figure 1 Map of Wismut's uranium mining and milling areas

\section{Remediation objectives and cover design criteria}

A major part of the waste rock materials and mill tailings on Wismut's mining sites is susceptible to acid rock drainage and/or is classified as radioactive matter with an activity of equal to or more than $200 \mathrm{~Bq} / \mathrm{kg}$ of the relevant nuclide (usually Radium-226). ARD resulting from waste rock materials is a major challenge to be addressed, given the large number of waste rock dumps from uranium mining and milling.

Remediation objectives to be met by a designed soil cover system design for ARD materials that are often also radioactive matter include the following:

- Ensuring human health and safety by avoiding direct access to radioactive matter, avoiding external radiation (direct radiation and dusting). This often includes institutional control on public access (fencing).

- Development of a safe and stable landform for the design life with respect to erosional stability by establishment of stable vegetation on the cover surface.

- Installation of a runoff diversion system on the object and the receiving streams, if needed, including runoff retention measures to ensure erosional stability and flood protection.

- Ensuring containment of the waste and seepage to the extent acceptable to the environment over the design life of the facility.

- Minimising oxygen intrusion (in order to control oxidation of the waste).

- Minimising percolation through the surface cover (to control contaminant seepage).

- Controlling gas exhalation (i.e., radon).

Based on the results of historical research of the operational period and the existing situation, investigation programs were prepared and carried out on a site-specific basis in order to obtain the data needed for 
evaluation of the preferred remediation option for each site. This paper focuses on selected sites where the need of surface covering was identified.

The design of a cover system for mine waste always depends on site-specific conditions. Moreover, design criteria must be developed based on site-specific investigations taking into consideration the type of mining or milling and the geochemical composition of ores and waste materials, as well as geochemical, geological, hydrogeological, geotechnical and hydrological aspects. Two key design factors for cover systems on mine waste that may produce acid rock drainage are site-specific climate conditions and the characteristics and availability of potential cover materials (O'Kane et al., 2011).

\section{$3 \quad$ Cover designs on Wismut's mining sites}

Since the 1990s, Wismut has placed soil covers on numerous waste rock dumps, mill tailings ponds and the backfilled Lichtenberg open pit as well as on contaminated sites. Most of the mine wastes covered are susceptible to acid rock drainage. The climate varies due to topography and can be characterised as moderately humid, with average temperatures of ca. $8.5^{\circ} \mathrm{C}$ and a central European winter and summer season.

This section describes a selection of the different cover designs planned and implemented on Wismut's mining sites: single-layer cover systems, two-layer cover systems, multilayer cover systems and partial covers consisting of a single-layer cover system.

The presented cover designs include two-layer covers designed specifically to address radon exhalation, single-layer and two-layer covers designed in accordance with store-and-release principles as well as to address radon exhalation and oxygen intrusion and multilayer-type covers built on the waste depository as well as the cover currently planned for parts of the area of Culmitzsch tailings pond.

\subsection{Single-layer cover}

The simplest design for a cover system is to construct only one layer of arable soil on the mine waste. This single-layer cover is usually constructed using well-graded sandy to loamy soil material. In association with vegetation established as part of the cover system, it should store and evaporate (release) the water infiltrated from precipitation. The thickness of the layer is dependent on climate and seasonal weather conditions at the site, the hydraulic characteristics of the cover material (i.e., moisture retention and permeability) and the planned vegetation (O'Kane et al., 2011).

A single-layer cover was installed over the backfilled Lichtenberg open pit (Figure 2). The upper $0.4 \mathrm{~m}$ thick loamy soil layer is clean soil while the lower $1.2 \mathrm{~m}$ of loamy soil is reused cover material. This layer is characterised as radioactively contaminated because it contains a percentage of radioactive waste rock materials. These waste rock materials were mixed in the course of relocation of this cover material from waste rock dumps in the Ronneburg mining area. With respect to soil-hydrological behaviour, both layers should be regarded as one single layer of $1.6 \mathrm{~m}$ thickness. The backfilled Lichtenberg open pit is located inside the Ronneburg underground mining area and is equipped with a water management and treatment system. The cover is designed to prevent any access to radioactive matter, to provide stable vegetation for the planned after-use (forest, grassland and locally others), to grant erosional stability and to minimise radon exhalation and oxygen intrusion. It is not specifically designed to limit the percolation rate.

The bottom illustration of Figure 2 shows the old single-layer cover placed during the 1980s on the Beerwalde WRD in the Ronneburg mining area. It was designed in accordance with similar design criteria to the cover on the backfilled Lichtenberg pit. It consists of a $1.2 \mathrm{~m}$ thick layer of silty loam. 


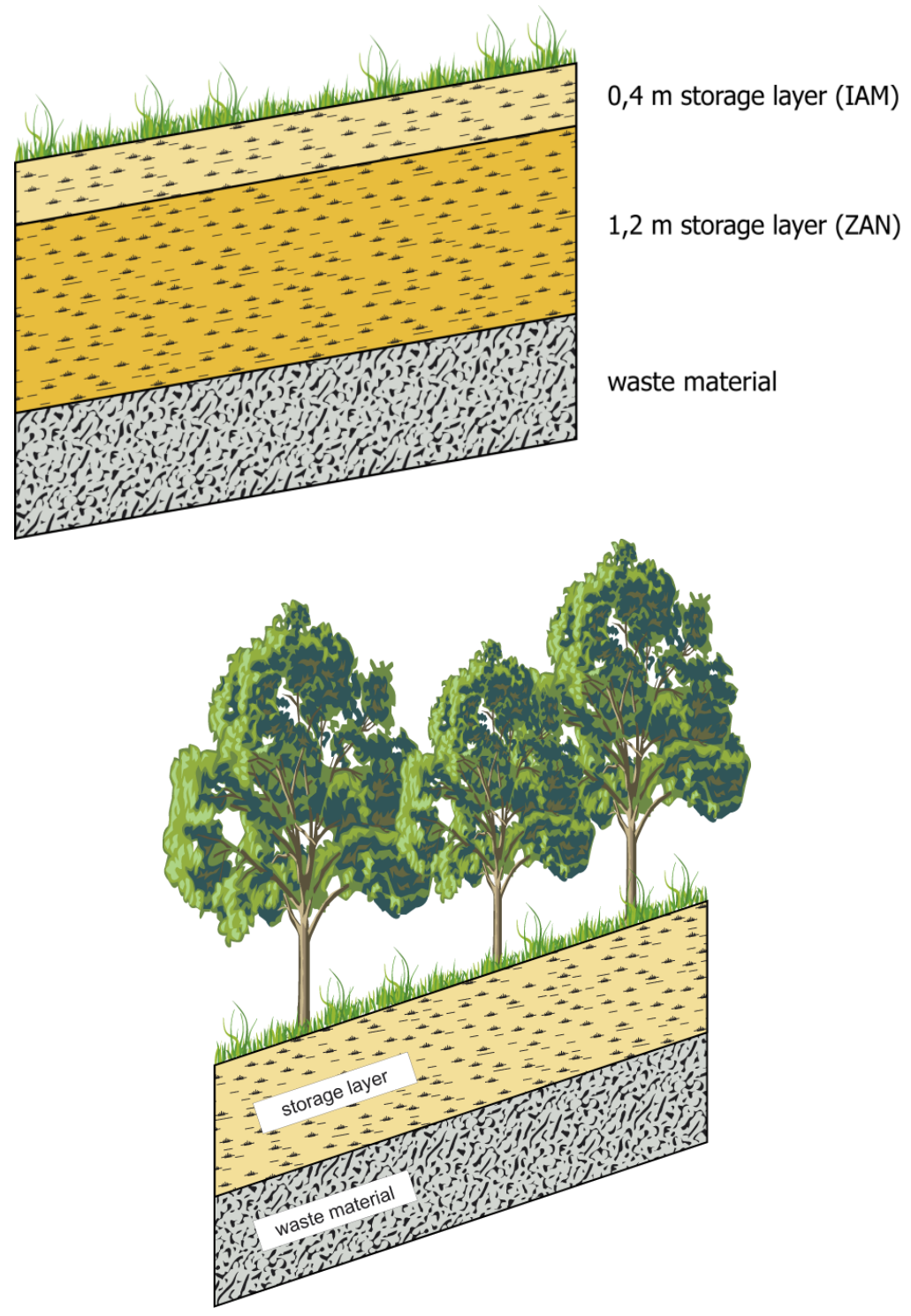

\section{Figure 2 Cover systems of backfilled Lichtenberg open pit (top) and local SW slope area of Beerwalde WRD (bottom)}

Similar single-layer covers consisting of approximately $1 \mathrm{~m}$ thick layer of mixed-grained soil were placed as temporary/interim covers on air-exposed sandy tailings surfaces similar to Truenzig tailings pond (Seelingstaedt). On Helmsdorf tailings pond, wastes from Crossen WRD were used as interim cover material to create a trafficable surface for further remedial works. Single-layer covers of approximately $1 \mathrm{~m}$ thickness were placed in the past on the entire tailings pond J1 of the Dammhalde/Trockenbecken (Johanngeorgenstadt). Single-layer covers of approximately $1.0-1.5 \mathrm{~m}$ thickness were also placed on numerous waste rock dumps, in particular on areas to be rehabilitated to allow agricultural land use.

Where it is only necessary to prevent direct access to the radioactive materials and ensure erosional stability of the surface to be reclaimed, the reshaped slopes of waste rock dumps are usually covered with a $0.5 \mathrm{~m}$ thick layer of clean soil (mixed-grained or fine-grained cohesive soil material). Such covers are vegetated with grass. If necessary, erosion protection mats are used to allow vegetation to establish.

The residual surfaces of relocated waste rock dumps as well as decontaminated mining sites have, if needed, been covered with a minimum of $0.3 \mathrm{~m}$ of clean soil (loam) for grasslands (open land or allowing for forest establishment). Remaining areas with radioactive contaminations of more than $1,000 \mathrm{~Bq} / \mathrm{kg} \mathrm{Ra}-$ 226 have commonly been covered with at least $1.5 \mathrm{~m}$ of clean soil. 


\subsection{Two-layer cover}

The two-layer cover typically consists of a storage layer like the single-layer system and an underlying sealing (barrier) layer. The storage layer consists of sandy to loamy soil material and is designed to store and evaporate the infiltration water. The underlying sealing layer is usually constructed using fine-grained soil material. The sealing layer needs to have a low permeability in order to reduce the percolation rate through the cover. The required permeability and the thickness of the sealing layer depend on climatic conditions at the site and the maximum tolerable percolation rate into the waste material. In most instances, the thickness of the overlying storage layer also strongly influences performance, as does the extent to which precipitation is able to run off the final landform. The sealing layer may only need to function until vegetation has been established.

Figure 3 shows the two-layer cover placed until 2002 on more than $90 \%$ of the surface of the Beerwalde WRD. It consists of a $1.5 \mathrm{~m}$ thick layer of sandy loamy soil underlain by a sealing layer (hydraulic conductivity $\mathrm{k}_{\mathrm{f}} \leq 1 * 10^{-9} \mathrm{~m} / \mathrm{s}$ ) of minimum thickness of $0.4 \mathrm{~m}$. The cover is designed to prevent direct access to radioactive materials as well as to minimise radon exhalation and oxygen intrusion. It must achieve erosional and geotechnical stability. The percolation rate should be controlled to be no more than $5 \%$ of the annual precitation rate after completion of the cover. Percolation rates through the cover over the long term can be controlled more and more by the store-and-release behaviour of the vegetative cover. The major part of the surface of the Beerwalde WRD was afforested. Figure 3 also shows the location and arrangement of the lysimeter installation.

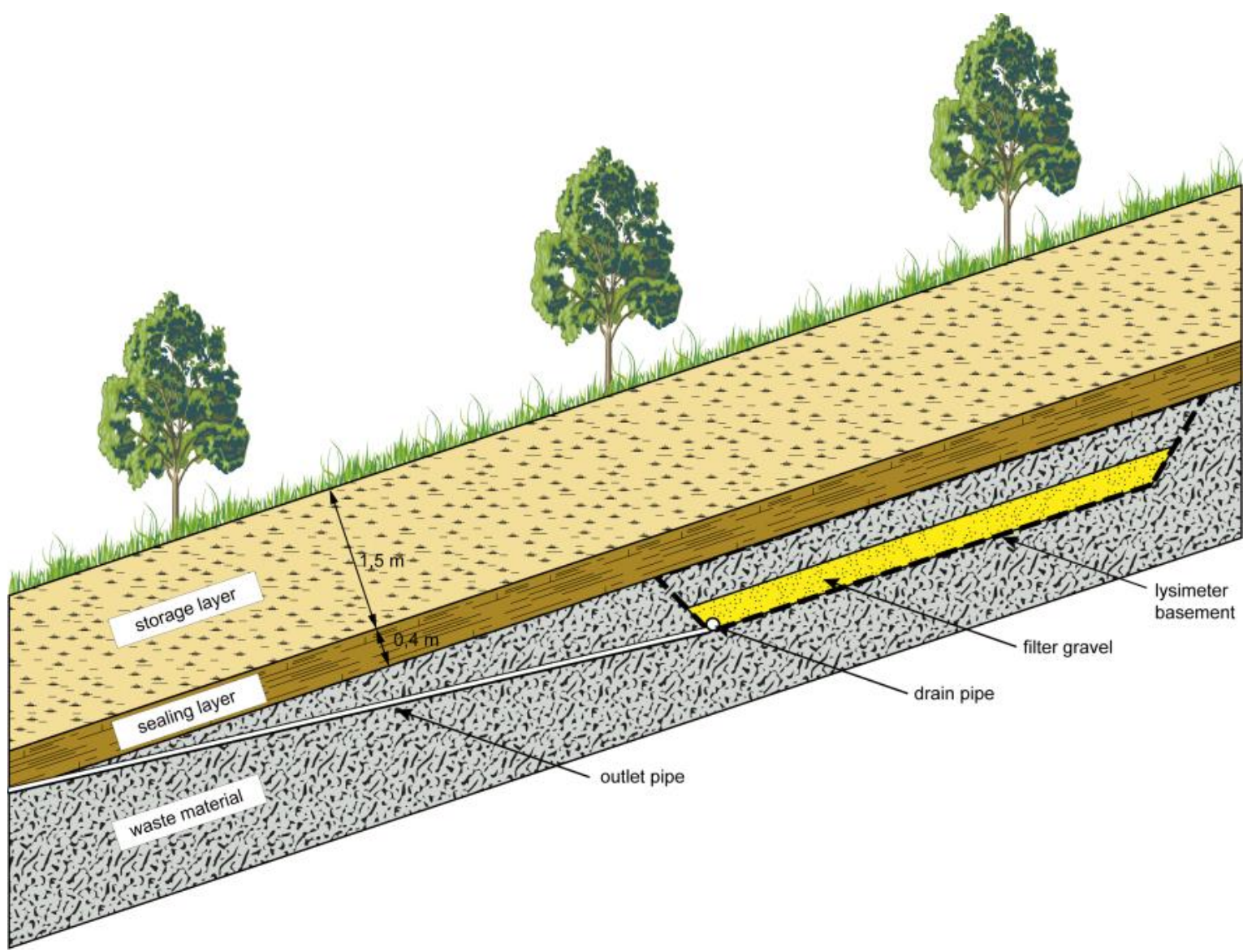

\section{Figure 3 Two-layer cover system at Beerwalde WRD (Ronneburg mining area)}

Figure 4 shows the design of the final cover placed on the sandy tailings beaches of the Trünzig tailings pond near the Seelingstädt mill. The final cover design for Trünzig tailings pond was completely permitted by 2006. It depended on the underlying tailings types. On sandy tailings beach zones, the final cover consists of a $2 \mathrm{~m}$ thick storage layer, including a compacted bottom lift $(0.5 \mathrm{~m}$; compaction degree $\geq 95 \%$ 
$D_{\operatorname{Pr}}$ of the Proctor density) above a compacted interim cover of $1 \mathrm{~m}$ thickness (compaction degree $\geq 95 \% \mathrm{DPr}_{\mathrm{pr}}$ and hydraulic conductivity $\mathrm{k}_{\mathrm{f}} \leq 5^{*} 10^{-9} \mathrm{~m} / \mathrm{s}$ ). The interim cover consists of mixed-grained soil from decomposed overburden rock relocated from a nearby waste rock dump of the former uranium open pit Trünzig-Katzendorf. Open-pit mining ended in 1957 before tailings disposal started. The final cover material consists of waste rock dump material (mixed-grained soil) from the Lokhalde waste rock dump located in the vicinity of the Culmitzsch tailings pond. On fine tailings zones, the functionality of the final cover shall be granted by a minimum $2.5 \mathrm{~m}$ thick layer consisting of mixed-grained waste dump material (from Lokhalde WRD and from the East WRD of Trünzig open pit). Among other requirements, the final cover is to prevent direct access to radioactive materials, minimise radon exhalation and oxygen intrusion, achieve erosional stability of the surfaces and provide sufficient plant available water during growing seasons. The final covering will be completed by 2013.

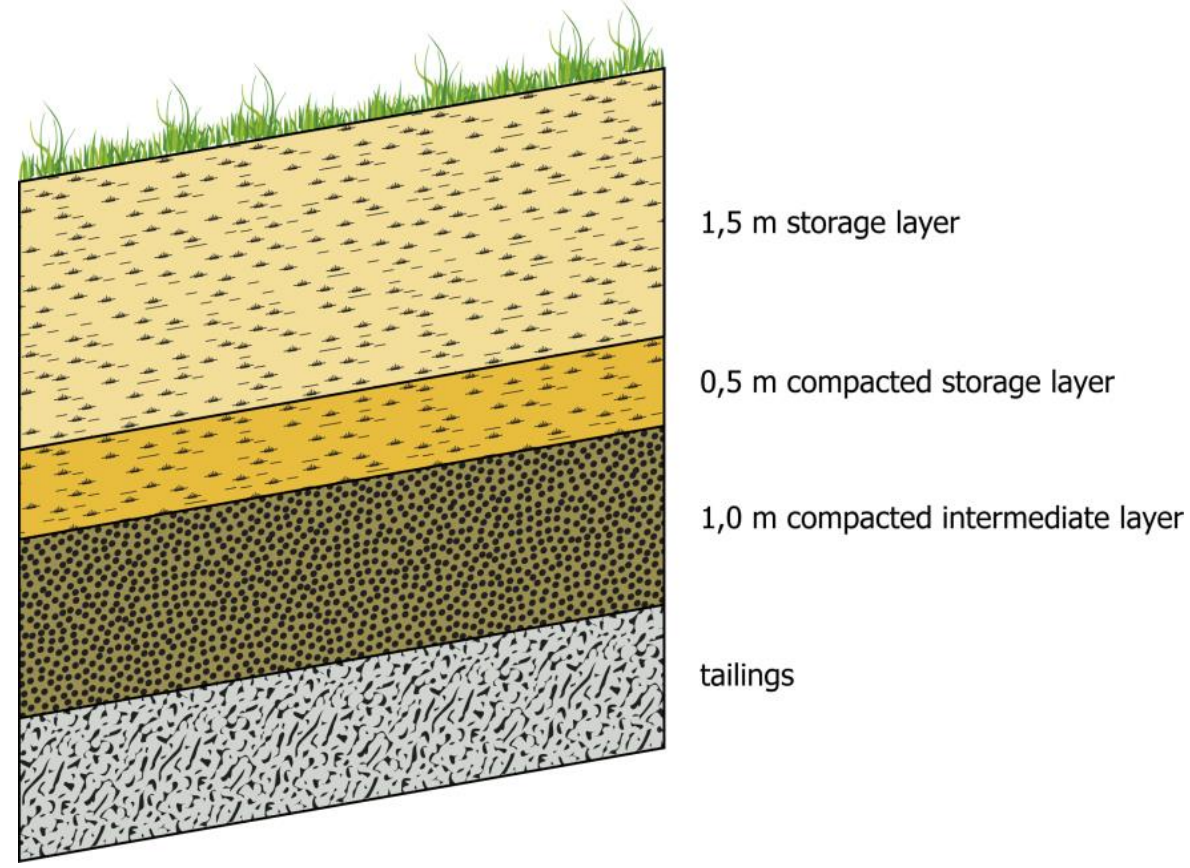

\section{Figure 4 Two-layer cover system on tailings beaches of Trünzig tailings pond (Seelingstaedt mining area and mill)}

Figure 5 presents the cover design of a different two-layer cover applied to many waste rock dumps located in the vicinity of villages or houses in the Aue mining area. This cover type is designed to minimise radon exhalation and provides sufficient plant-available water for vegetation to achieve erosion protection and to allow for recultivation as grassland or forestland. Minimisation of the percolation rate is not essential.

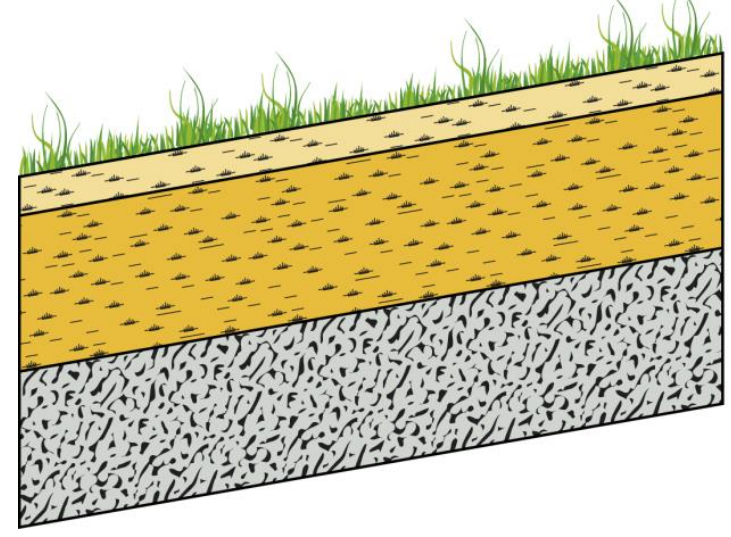

0,2 m storage layer (top soil)

recultivation substrate blends

$0,8 \mathrm{~m}$ storage layer (mineral soil)

waste material

Figure 5 Two-layer cover on Borbachdamm WRD and WRD \#366 (Aue mining area) 
The cover has two layers. The lower layer with a thickness of $0.8 \mathrm{~m}$ ensures a reduction of radon gas release and is made of cohesive soil. To reduce the initial radon flux from the uncovered waste rock dump surface by about $75 \%$, the cover soil has to be characterised by a long-term gas permeability of $<10^{-12} \mathrm{~m}^{2}$. The upper layer is made of topsoil and has a thickness of about $0.2 \mathrm{~m}$ to support vegetation. The Borbachdamm WRD within the Aue mining area was covered to this specification by 2000 . The lower layer of total thickness of $0.8 \mathrm{~m}$ was placed in two interlocking lifts of $0.4 \mathrm{~m}$ each of sandy-loamy silt. The mineral soil has low air void (approximately $3 \% \mathrm{vol}$ ), an available field capacity in the order of $20 \%$ vol and a comparatively low effective hydraulic conductivity of $10^{-7} \mathrm{~m} / \mathrm{s}$. The overlying $0.2 \mathrm{~m}$ thick topsoil is made of organic recultivation substrate produced by the composting of residual organic materials. Following placement, this substrate was intermingled with the topsoil cover. The topsoil exhibits high hydraulic conductivity $\left(10^{-4} \mathrm{~m} / \mathrm{s}\right)$ and the available field capacity is on the order of approximately $23 \%$ vol. Waste rock dump \#366 has a volume of 7.5 million $\mathrm{m}^{3}$, making it one of the largest at the Bad Schlema site. Remediation of the dump took place from 1997 to 2004 . The cover design is similar to that placed on the Borbachdamm waste rock dump. The soil is again sandy loam with an available field capacity of $16 \%$ vol. Its effective hydraulic conductivity of $2 * 10^{-7} \mathrm{~m} / \mathrm{s}$ is slightly higher than at the Borbachdamm WRD.

\subsection{Multilayer-type cover}

The multilayer-type cover system includes several different types of cover layers. It usually consists of a storage (and recultivation) top layer, an underlying drainage layer and a sealing layer. At some locations it may be necessary to complete this cover system using geomembrane products or other artificial sealing materials. Typically, the multilayer-type cover also requires geotextiles or a suffusion prevention layer to ensure functionality of the drainage layer. In addition, a bedding layer is sometimes needed below the sealing layer. Such cover systems are typically applied on waste depositories for hazardous wastes (O'Kane et al., 2011). The objective of the drainage layer is to reduce the hydraulic head on the sealing layer and thus the percolation rate through the sealing layer. A geomembrane may be needed where it is necessary to reduce the percolation rate into the waste material to very low rates.

Wismut applied the multilayer cover on the Lichtenberg waste depository. This waste depository was constructed in 1998-99 for the disposal of mixed-contaminated wastes from remediation of uranium mining sites. To date it is nearly completely filled up. The surface cover to this facility consists of the following layers from top to bottom: topsoil layer (loamy soil); geotextile, drainage layer (gravel, $\mathrm{k}_{\mathrm{f}} \geq 3^{*} 10^{-3}$ $\mathrm{m} / \mathrm{s}$ ); geomembrane (HDPE, $2.5 \mathrm{~mm}$ thickness); and $0.5 \mathrm{~m}$ sealing layer (silty clay soil, $\mathrm{k}_{\mathrm{f}} \leq 5^{*} 10^{-9} \mathrm{~m} / \mathrm{s}$ ). Since the beginning of the soil-hydrological monitoring a water balance developed in the topsoil layer due to climatic conditions and vegetation establishment. To date no percolation has been observed through the geomembrane and sealing layer. The cover surface is mowed annually.

In 2012 Wismut filed an application for surface covering of the recontoured Culmitzsch tailings pond close to Seelingstädt. The final cover design is based on an object-specific conceptual site model for the prediction of contaminant transport from the sources (tailings) to the receiving streams. The cover design was approved by the authorities in early 2011 for evaluation of the optimum final cover design with respect to the underlying tailings types and hydrological as well as hydrogeological conditions. This enables Wismut to verify the performance of the cover and from this refine the final cover design. For the fine tailings zones and transition zones, the cover design is similar to the cover already constructed on the Trünzig tailings pond. Applied only on tailings beaches and in the transition zones next to the tailings beaches, the cover design is a multilayer type cover without artificial materials. It consists of a $1.5 \mathrm{~m}$ thick storage layer (clean silty loam) underlain by a drainage layer of $0.3-0.5 \mathrm{~m}$ thickness $\left(\mathrm{k}_{\mathrm{f}} \geq 1 * 10^{-4} \mathrm{~m} / \mathrm{s}\right)$ underlain by a compacted layer of mixed-grained soil material from the Lokhalde WRD. This soil comes from decomposed overburden rock of the waste rock dump from the ancient Culmitzsch open pit. It is compacted $D_{\operatorname{pr}} \geq 95 \%$ compaction degree, having a hydraulic conductivity $k_{f} \leq 5^{*} 10^{-9} \mathrm{~m} / \mathrm{s}$. The cover profile is presented with Figure 6 . 


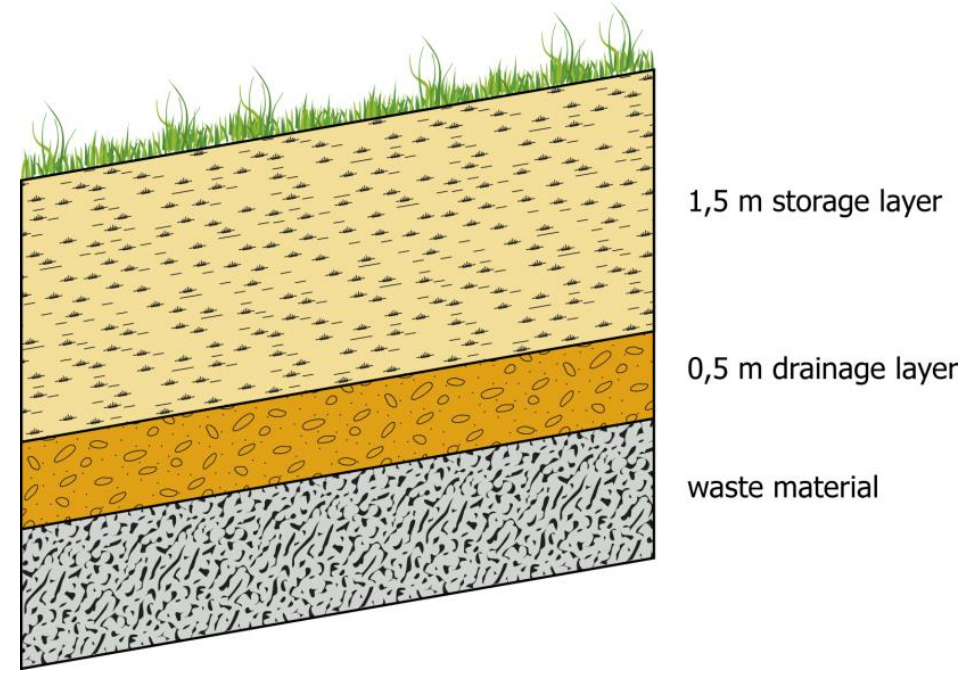

Figure 6 Planned multilayer cover on tailings beaches of Culmitzsch tailings pond (Seelingstädt mining area and mill)

\subsection{Single-layer covers on selected areas of waste rock dumps}

Partial covering is a remediation solution applied to improve the radon control with minor impairment of nature and landscape. It typically consists of a single-layer cover of 1-1.5 m thickness constructed over a part of the area of a waste rock dump. A partial cover was used for remediation of the waste rock dump Zentralschachthalde in Johanngeorgenstadt. The following description refers to the case study presented by Regner and Schulz (2008). Figure 7 shows a schematic map indicating the location of the 'partial cover'.

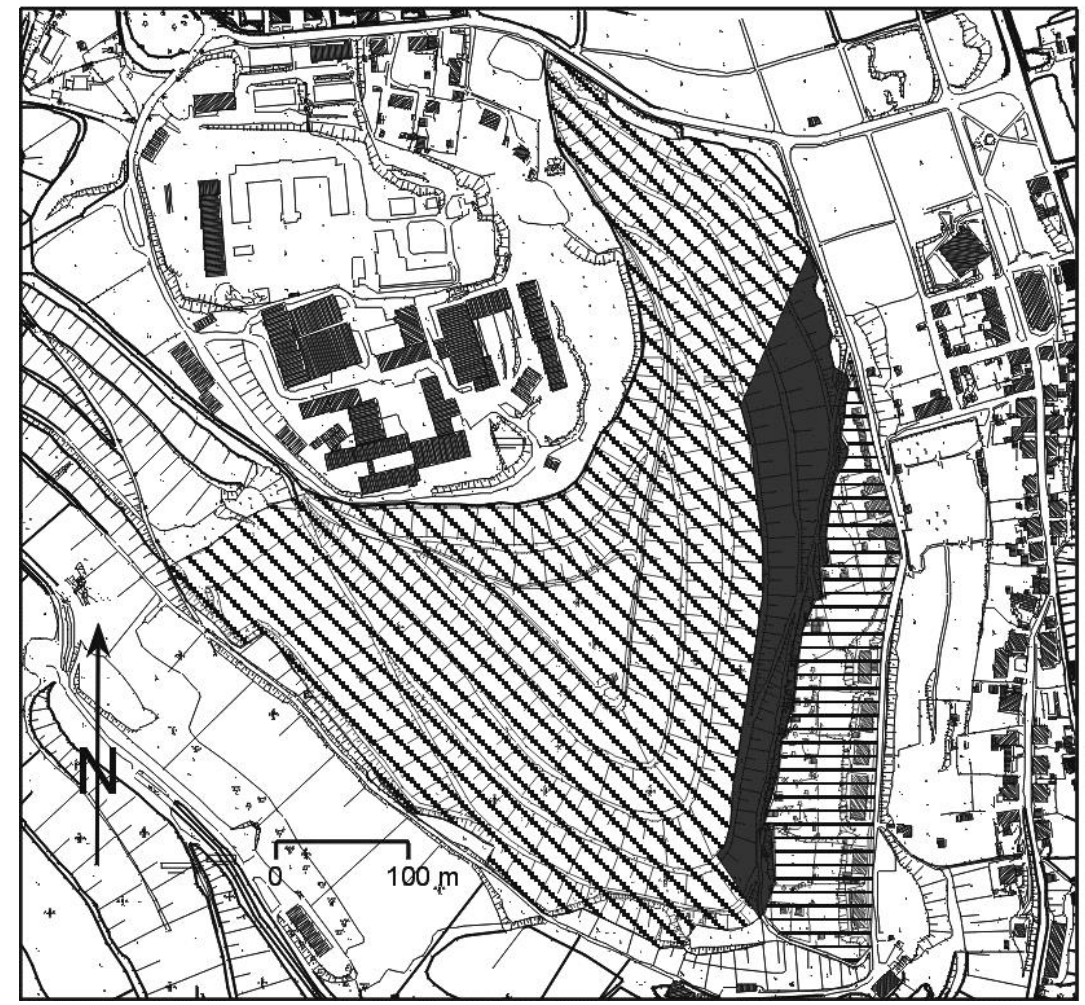

Legend:

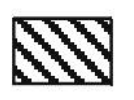

Area of the eastern part of the „Zentralschachthalde" waste rock dump without covering

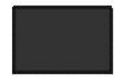

Remediation area of the "Zentralschachthalde" covering made of cohesive soil

Relevant housing areas and garden land

\section{Figure 7 Remediation solution for the waste rock dump Zentralschachthalde (Johanngeorgenstadt) (Regner and Schulz, 2008)}

An investigation of the exposure situation at formerly abandoned Wismut sites showed that unacceptable effective doses are received by people living in the vicinity of the waste rock dumps. A significant reduction of such radiological impact is one of the main objectives of the remediation of the waste rock dumps. 
Levels of exposure depend on the site-specific conditions and the relevant exposure pathways. In some cases, housing areas situated in the neighbourhood of big or midsize waste rock dumps experienced 'inhalation of radon and radon daughters' as the dominant exposure pathway. This is not only a result of the increased specific activities of Ra-226 of the waste rocks and the elevated radon release due to convection processes but also of the advective radon transport from the waste rock dumps towards the housing areas. One waste rock dump showed a radon release behaviour that is rather complex over area and time, whereby the radon release is mainly due to convective processes induced in the waste rock dump.

Convective radon release processes become manifest in pronounced diurnal variations as well as annual variations (Regner and Schulz, 2008). From Figure 7 one can see that housing areas and garden land exist in close proximity to the waste rock dump. The radon exposure situation is characterised by significant radon releases at the toe of the waste rock dump due to convective transport processes during the summer season. For this radon release mechanism, the minimum-cost and most effective remediation solution entails a partial covering of the toe region and not of the entire waste rock dump.

The partial covering has to be designed taking into consideration that the convective radon release is strongly suppressed by a reduction in the soil gas flow. The investigations have shown that a 'cover belt' with a width of $30-100 \mathrm{~m}$, depending on the location, and a thickness of about $1 \mathrm{~m}$ is sufficient to drastically reduce the radon release in the summer season. However, even in the winter season radon release from the top surface of the waste rock dump is significantly reduced, since partial cover significantly reduces the soil air flow through the dump. The covered area in comparison with the total area of the waste rock dump is shown in Figure 7.

A similar partial cover will be constructed in 2013 as part of the ongoing remediation of the waste rock dump \#54 in Johanngeorgenstadt. The permitted cover design consists of a single-layer cover made of loamy soil with a thickness of $1 \mathrm{~m}$ at the top and a minimum of $1.5 \mathrm{~m}$ at the bottom of the slope. Along the slope toe, a trench is being excavated down to the rock surface. This trench will be backfilled with loamy soil and compacted in layers to build up a vertical seal. This sealing will reduce radon exhalation along or under the cover at the toe of the slope. The cover will stay as grassland with some minor shrubs so as not to affect wind blow along this part of the valley.

\section{Synopsis on the functional performance of the realised cover designs}

Experiences and observations made during construction and monitoring after construction as well as lessons learned regarding the functional performance of the covers are presented in the following synopsis. Table 1 lists the annual percolation rates of different cover types measured at selected hydrological monitoring stations installed in the covers. The data are presented in more detail in Schramm and Roscher (2013) and in Merkel and Lindner (2013). 
Table 1 Results of Lysimeter Measurements RU [mm] at Wismut sites

\begin{tabular}{cccccccccccccc}
\hline Year & 2001 & 2002 & 2003 & 2004 & 2005 & 2006 & 2007 & $\mathbf{2 0 0 8}$ & $\mathbf{2 0 0 9}$ & $\mathbf{2 0 1 0}$ & $\mathbf{2 0 1 1}$ & $\mathbf{2 0 1 2}$ & $\varnothing$ \\
\hline $\begin{array}{c}\text { Borbach- } \\
\text { damm WRD }\end{array}$ & 416 & 959 & 261 & 166 & 234 & 231 & 530 & 272 & 497 & 576 & 279 & 282 & 392 \\
$\begin{array}{c}\text { WRD \#366- } \\
\text { GL 115 }\end{array}$ & - & 625 & 113 & 267 & 277 & 171 & 221 & 166 & 180 & 441 & 136 & 138 & 249 \\
$\begin{array}{c}\text { Beerwalde } \\
\text { WRD - MS2 }\end{array}$ & - & 4 & 4 & 2 & 1 & 6 & 0 & 8 & 8 & 9 & 19 & 43 & 10 \\
$\begin{array}{c}\text { Beerwalde } \\
\text { WRD -MS7 }\end{array}$ & - & - & 10 & 8 & 25 & 24 & 73 & 31 & 119 & 173 & 43 & 3 & 51 \\
$\begin{array}{c}\text { Beerwalde } \\
\text { WRD - MS4 }\end{array}$ & - & 230 & 107 & 48 & 78 & 77 & 63 & 100 & 85 & 204 & 98 & 3 & 86 \\
$\begin{array}{c}\text { Oppen pit } \\
\text { Lichtenberg } \\
\text { MS5 }\end{array}$ & - & - & - & - & - & - & 108 & 139 & - & - & 77 & 53 & 94 \\
\hline
\end{tabular}

Figures 8-12 present aerial views made in 2012 of the remediation cases described above.

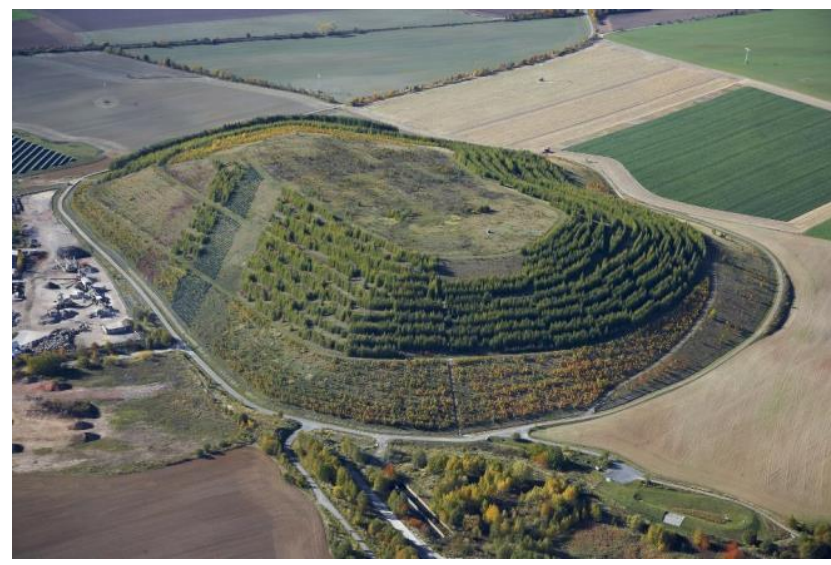

Figure 8 Covered Beerwalde WRD in 2012 2012 (view from East)

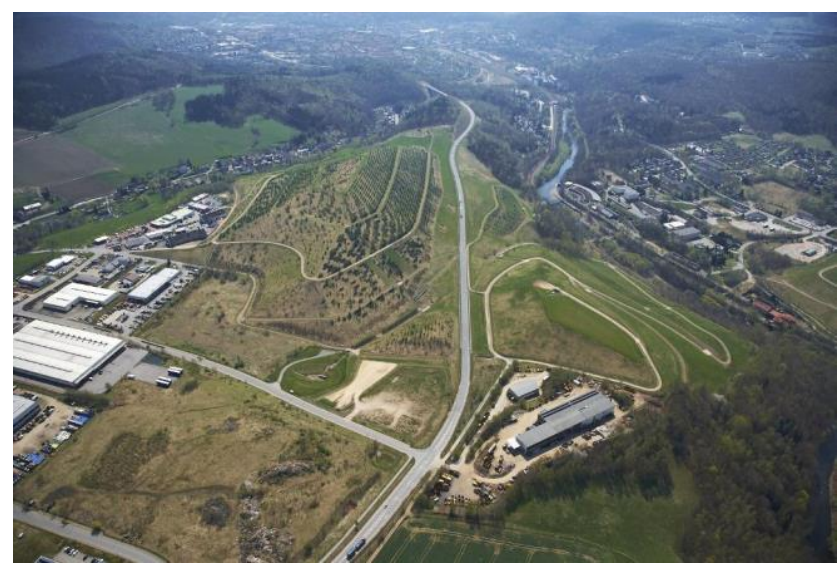

Figure 10 Covered WRD \#366 in 2012

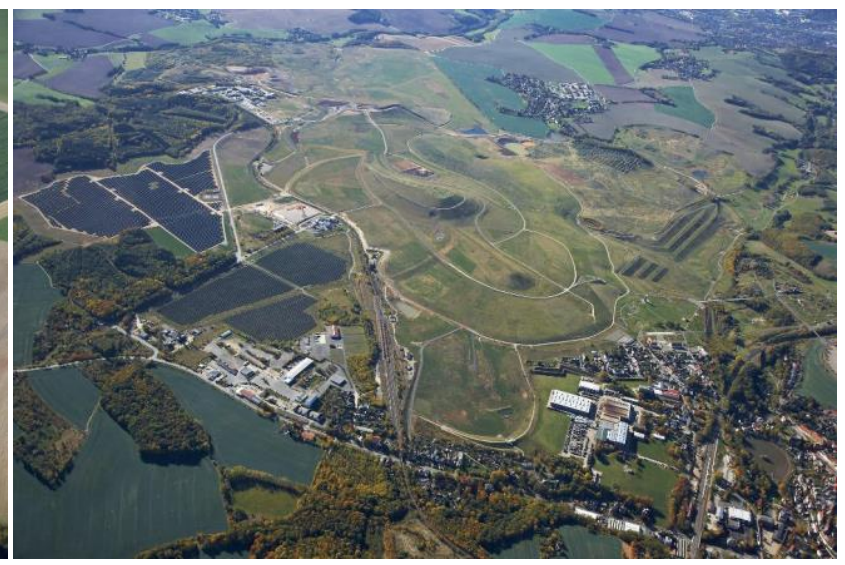

Figure 9 Covered Lichtenberg open pit (view from NE)

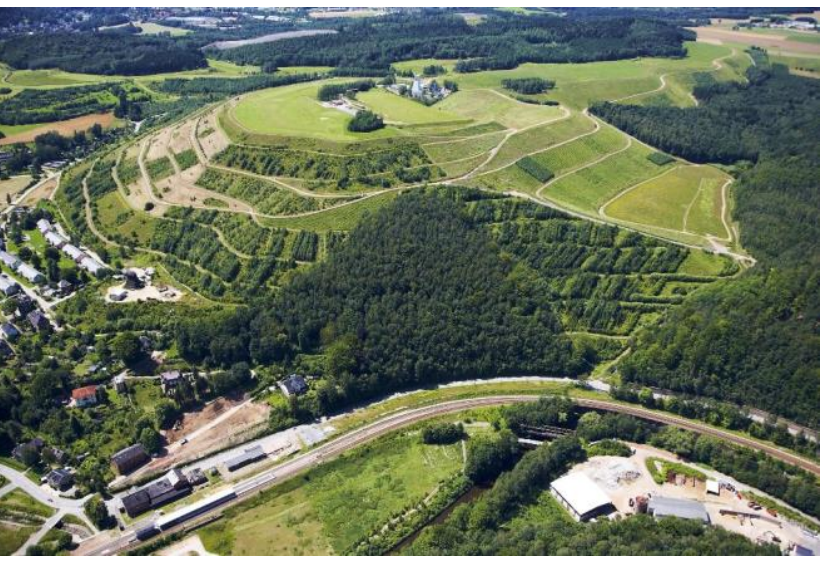

Figure 11 Covered WRD \#38old with WRD Borbachdamm in 2012 


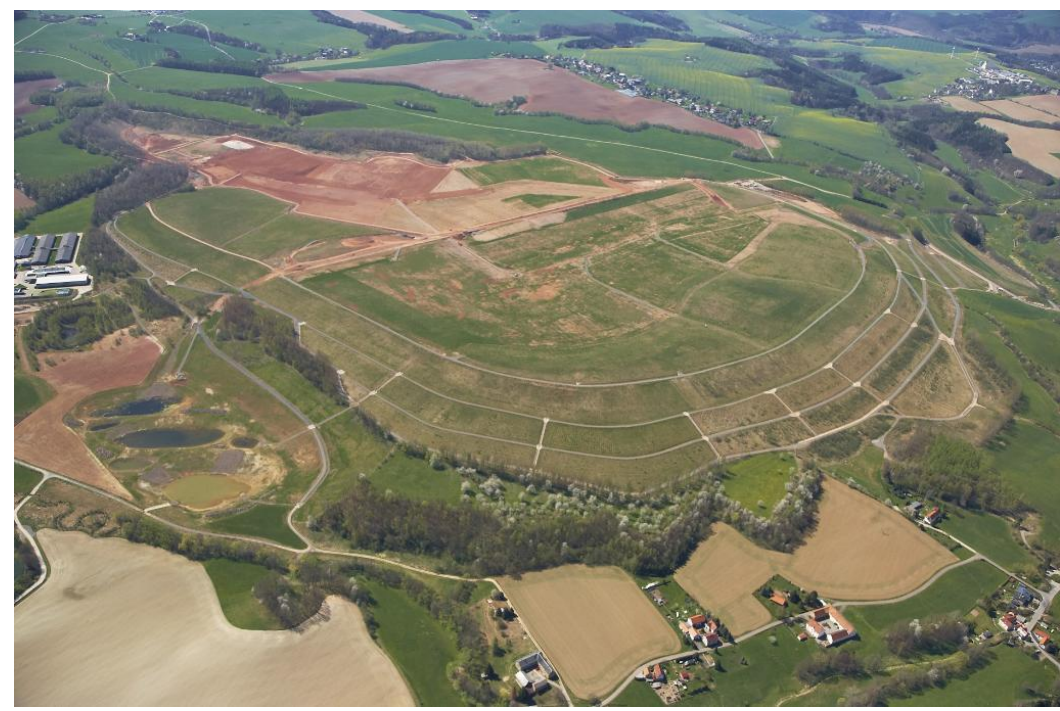

\section{Figure 12 Trünzig tailings pond in 2012 (final covering ongoing in the background)}

\subsection{Single-layer covers and two-layer cover without a sealing layer}

Experiences made during construction and monitoring show that single-layer covers are robust and easy to construct. For erosion protection, grass should be seeded immediately after cover construction.

At the MS 4 on Beerwalde WRD, the water balance of the $1.2 \mathrm{~m}$ thick single-layer cover with southwestern exposition and mature forest vegetation has been monitored. This cover can be seen as representative for the long term of such single-layer covers. A mean net percolation rate of $13 \%$ of precipitation (max. $28.6 \%$ of precipitation) was measured here.

Similar results for the percolation rate on the monitoring stations on the covered and backfilled Lichtenberg open pit were obtained even with a cover consisting of loamy soil of $1.6 \mathrm{~m}$ total thickness. Radon emanation measurements proved that the requirements with regard to radon exhalation were met during the entire monitoring period. The influence on radon exhalation - and specifically whether this increased due to the establishment of forests - could not be observed. This may be a result of the younger status of forest establishment together with the larger thickness of at least $1.6 \mathrm{~m}$ of loamy soil. During the entire monitoring period, oxygen measurements showed that oxygen moves through the cover but is used up in the uppermost few meters of the underlying waste rock material where there is generally at least a $10 \mathrm{~m}$ thick zone of mildly-acid-generating materials. This is in line with the design of the cover system and the behaviour of the underlying waste rock materials.

The hydrological researchers at Schlema-Alberoda and Ronneburg site showed the effect of the maturation of the vegetation to cover performance as well. The two-layer soil cover in combination with plant cover is able to reduce the net percolation rate through the WRDs at Schlema-Alberoda site to about one-third of the precipitation. The higher values of net percolation are due to the smaller thickness of $1 \mathrm{~m}$ and of the mountain-induced climate.

Simultaneous measurements of radon exhalation in the immediate vicinity of the monitoring sites WRD \#366 and WRD Borbachdamm show the important influence of the water balance on radon emanation. Low water saturation levels in the soil due to evapotranspiration by trees and shrubs lead to increased radon emanation, especially during summer. This could be avoided by regular mowing or pasture. If trees or shrubs are to be propagated, both the cover and landscape design needs to take into account the potential for increased radon emanation on the exposure pathways.

We also observed that the geotechnical stability of two-layer covers with an organic topsoil layer could be a problem on steep slopes ( $v: h=1: 2.5)$, in particular near berms, during wet seasons or during spring freshette. Local slope failures were observed and needed repairs even more than five years after cover completion. 


\subsection{Two-layer covers with sealing layer}

Observations during construction show that construction of two-layer covers required careful implementation of a proper QA/QC-program and construction supervision. Two-layer covers are in principle robust. However, special attention needs to be paid to geotechnical stability of the covers on slopes.

The storage layer on Beerwalde WRD was made by mixing sand and loam. This mixing led to some heterogeneous distribution of more sandy and more loamy parts within the storage layer. After hydrological monitoring stations were installed in 2001/12, it became clear that the catchment area of any collection system needs to be clearly defined. Therefore the design of the lysimeter post-installation was changed. Today all lysimeters collect water from a closed area that excludes any lateral inflow.

During the first years after cover completion, it was noticed that geotechnical stability on steep slopes $(v: h=1: s 3)$ could be problematic. Slope failures were observed at berms and needed repair works.

Measurements at the hydrological monitoring stations on the Beerwalde WRD show an enhanced real evapotranspiration performance during the reported period. The orientation of slopes and vegetation status strongly influence the water balance and consequently the percolation rate through the sealing layer. The measurements show the major influence of slope orientation on vegetation development and roots depth under the given climate conditions. On the southwestern slope, the percolation through the sealing layer at monitoring station 7 (MS 7) was increasing with time until 2010. At MS 2, which is northfacing, the annual percolation rate remained constant at 1.4\% until 2010 and has increased since then to a maximum of $6.9 \%$. Hence the measurements show a transitional stage of the cover development after closure, after which they follow the trend of the cover with southwestern orientation.

The measurements also show that under given climate conditions over the long term a mean net percolation rate of no more than $5 \%$ of the annual precipitation rate can only be achieved through a multilayer type cover with a sealing layer $\left(\mathrm{k}_{\mathrm{f}} \leq 1 * 10^{-9} \mathrm{~m} / \mathrm{s}\right)$, a drainage layer and a storage layer of appropriate thickness.

At Trünzig, no influence of growing vegetation on the percolation rate was observed. Here the vegetation is still small. The monitoring results show that radon exhalation and oxygen ingress are completely negated by the cover.

\subsection{Multilayer type cover}

The construction of a multilayer type covers needs implementation of a detailed quality assurance program and daily construction supervision on the site. It should be remembered that the functionality of artificial materials cannot be guaranteed over the long term, in particular with respect to design periods of 200-1,000 years.

Notwithstanding this limitation, on the Lichtenberg waste depository there was no percolation measured through the geomembrane and the underlying sealing layer. The water balance in the storage layer is influenced by the actual status of a fully developed grassland with some small shrubs. The cover surface is mowed annually. The permitted monitoring program prescribes in detail the monitoring regarding water balance of the final cover, performance of the base sealing system, seepage water collection and treatment as well as groundwater flow and groundwater quality. The cover needs institutional control and maintenance and repair measures over the long term.

The multilayer type cover planned for the tailings beaches of Culmitzsch tailings pond should reduce the overall infiltration into the tailings pond to control the contaminant load via the groundwater path to the receiving streams. Its performance can be verified only by applying a site-specific numerical model for contaminant transport. 


\subsection{Single-layer cover on partial areas of waste rock dumps}

Single-layer covers on partial areas of a waste rock dump are aimed at the suppression of radiation exposure by radon. The first radon measurements performed on the waste rock dump Zentralschachthalde, located in the town of Johanngeorgenstadt (Saxony), after completion of the cover construction have proved the effectiveness of the adopted approach whereby a partial cover has been constructed over the waste rock dump. Thus during the summer season the radon concentration at a height of $1.5 \mathrm{~m}$ above the ground has been reduced from $220 \mathrm{~Bq} / \mathrm{m}^{3}$ to $<30 \mathrm{~Bq} / \mathrm{m}^{3}$. This means the associated exposure dose due to radon is now well below $1 \mathrm{mSv} / \mathrm{a}$ (Regner and Schulz, 2008).

Based on these positive results, similar remediation solutions have been planned for the waste rock dump \#54 in Johanngeorgenstadt. This remediation is currently ongoing and scheduled to be completed by the end of 2013.

\section{$5 \quad$ Conclusions}

The design objectives of a cover system are highly dependent on the specific site considerations. But the design approach or methodology is not site-specific. Through monitoring of large-scale field trials and fullscale covers, an opportunity exists to continue to advance cover system design, such that greater confidence with predicting performance can be achieved (O'Kane et al., 2011).

Monitoring of covers at Wismut shows the importance of vegetation in the water balance of waste rock dump covers. Specifically, interception, evaporation and in particular transpiration are of major importance. Measurements taken on all covers without a sealing layer lead to the conclusion that within a few years the water balance of a cover system built along the lines of a store-and-release design can achieve an equilibrium condition. Once dense-growing vegetation is established, cover percolation drops to virtually zero during the summer months. As vegetation development progresses, the calibrated annual model-based water balances provide evidence for the expected change of water balance dominance in favour of real evapotranspiration.

Two-layer covers with a sealing layer show in principle a slower increase of the percolation rate resulting from desaturation of the cover by plant growth. At Beerwalde WRD, the percolation rate exceeded $5 \%$ six years after cover completion. This leads to the conclusion that if such a net percolation rate criterion is to be met over the long term for the given climatic conditions, either a multilayer cover including a storage layer, a drainage layer and a sealing layer or a very thick storage layer will be required. The two-layer cover successfully reduces oxygen ingress and radon exhalation.

Special remediation solutions like single-layer covers on partial areas of waste rock dumps are preferred for specific remediation objectives, usually where the primary objective is to reduce radiation exposure due to radon exhalation from waste rock dumps.

\section{References}

O'Kane, M., Roscher, M. and Barnekow, U. (2011) Hydrology of soil covers on mine wastes - selected examples of Wismut and international experiences, Nachhaltigkeit und Langzeitaspekte bei der Sanierung von Uranbergbau- und Aufbereitungsstandorten, in Proceedings des Internationalen Bergbausymposiums WISSYM2011, 25-27 May 2011, Wismut GmbH, Ronneburg, Germany, pp. 167-185.

Merkel, G. and Lindner, S. (2013) Design, construction and monitoring of the final cover on Wismut's Truenzig tailings pond, in Proceedings Eighth International Conference on Mine Closure (Mine Closure 2013), M. Tibbett, A.B. Fourie and C. Digby (eds), 18-20 September 2013, Cornwall, United Kingdom, Australian Centre for Geomechanics, Perth.

Regner, J. and Schulz, H. (2008) Development of an object-specific remediation solution, for the waste rock dumps at the formerly abandoned Wismut sites, KERNTECHNIK, Vol. 73(3), pp. 1-5.

Schramm, A. and Roscher, M. (2013) Two-layer soil covers on selected radioactive waste rock dumps at Wismut - results of more than 10 years of hydrological monitoring, in Proceedings Eighth International Conference on Mine Closure (Mine Closure 2013), M. Tibbett, A.B. Fourie and C. Digby (eds), 18-20 September 2013, Cornwall, United Kingdom, Australian Centre for Geomechanics, Perth. 